\title{
EXPERIENCE WITH ARTERIOVENOUS FISTULAS FOR CHRONIC HEMODIALYSIS IN CHILDREN: TECHNICAL DETAILS AND REFINEMENTS
}

\author{
Uenis Tannuri and Ana Cristina Aoun Tannuri
}

\begin{abstract}
TANNURI U et al. Experience with arteriovenous fistulas for chronic hemodialysis in children: technical details and refinements. CLINICS 60(1):37-40, 2005.
\end{abstract}

PURPOSE: The aim of this paper is to report our experience in the creation of arteriovenous fistulas in children by using microsurgical vascular techniques, with emphasis on the details of the surgical technique.

METHODS: The children underwent surgery from July 1997 to March 2004. Operating loupes (magnification: 3.5X) were used by the entire surgical team. After dissection and adequate mobilization, the vein was anastomosed to the artery in an end-to-lateral fashion by using 4 separate $7 / 0$ or $8 / 0$ prolene running sutures.

RESULTS: Twenty nine children underwent 33 fistula creations - 21 radiocephalic, 6 brachiocephalic, 4 brachiobasilic, and 2 saphenofemoral. Primary patency was achieved in 17/21 (80.9\%) of the radiocephalic fistulas, 5/6(83.3\%) of the brachiocephalic, $3 / 4(75.0 \%)$ of the brachiobasilic, and 2/2 (100\%) of saphenofemoral. Two patients developed fistula occlusion and radial artery thrombosis, and in 2 others, radiocephalic fistulas became occluded in the first or second postoperative week. In the late postoperative period, the saphenofemoral fistulas were responsible for significant edema formation in the lower extremity; an aneurysm formed in a brachiocephalic fistula after a long period of utilization. As to the patency of the different sites of fistulas, the brachiocephalic and brachiobasilic fistulas had the same incidence of patency as the radiocephalic fistulas $(P>.05)$.

CONCLUSIONS: This experience indicates that the arteriovenous fistulas are a satisfactory method for providing hemodialysis in children. The utilization of microsurgical techniques and some technical refinements herein described permit the attainment of high patency rates of the fistulas.

KEYWORDS: Vascular access. Arteriovenous fistula. Hemodialysis. Veins.

Revolutionary changes in the management of renal failure in infancy and childhood are occurring as a consequence of the application of new techniques of dialysis and transplantation to children with end-stage renal disease. However, relatively few institutions involved in the management of children with renal failure have had the opportunity to accumulate a large amount of experience in pediatric hemodialysis. Vascular access is the basis for chronic hemodialysis and persists as a surgical challenge, especially for pediatric patients. As a first choice, external

From the Paediatrics Surgery Division and the Children's Institute, Hospital das Clínicas, Faculty of Medicine, University of São Paulo - São Paulo/SP, Brazil.

E-mail: uenist@usp.br

Received for publication on June 03, 2004.

Accepted for publication on August 10, 2004. central venous catheters are usually utilized, but they restrict the child's physical activity and usually do not last for a long time because of complications due to infection. In 1966, arteriovenous fistulas (AVFs) were introduced by Breschia and Cimino as a standard procedure for chronic hemodialysis in adult patients. ${ }^{1}$

Following the early experience in adult patients, the first successful creation of AVFs in children was reported in $1970 .^{2}$ Three years later, Broyer et al. reported that $54 \%$ of distal fistulas in children who weighed less than $20 \mathrm{~kg}$ had good results. ${ }^{3}$ In 1981 the utilization of microsurgical techniques for the creation of AVFs in children who weighed less than $10 \mathrm{~kg}$ was first reported. ${ }^{4}$ After these studies, the importance of microsurgery began to be stressed on account of the high patency rate of the AVFs in children. ${ }^{5}$ 
In 1997 we started performing AVFs in children with end-stage renal disease in our institution. The aim of this retrospective analysis is to report this experience of using microsurgical vascular techniques with emphasis on the details of the surgical technique.

\section{MATERIALSAND METHODS}

The children underwent surgery between July 1997 and March 2004. All procedures were performed by the first author. Whenever possible, the nondominant arm was chosen for the AVF creation. Preoperative evaluation in all cases consisted of a detailed clinical evaluation of the vessels of the nondominant arm. No venographic assessment was performed.

Operating loupes (magnification: $3.5 \mathrm{X}$ ) and microsurgical techniques were used by the entire surgical team in all cases. The patients underwent general anesthesia and brachial plexus block for regional anesthesia. The radiocephalic fistula was always the first choice and was performed whenever the cephalic vein was visible. The arm ischemia technique with an inflatable tourniquet was not utilized.

For the creation of a radiocephalic fistula, a $3-\mathrm{cm}$ longitudinal incision through the skin was made halfway between the cephalic vein and the radial artery at the wrist. The cephalic vein was dissected first, and its collateral branches were then carefully ligated near the main trunk. The dissection was conducted up to the bifurcation of the vein at the dorsal aspect of hand. At this site, the vein was ligated and sectioned. Adequate mobilization is of the utmost importance to prevent kinking after the establishment of the fistula. The adventitia was dissected from the exposed vein to allow for dilatation of the vein by the increased arterial pressure. A thin catheter was introduced into the proximal segment of the vein, and 10 to $20 \mathrm{~mL}$ of heparin saline solution was injected to dilate the vein. The proximal end of the vein was spatulated by performing a 5 to 7 $\mathrm{mm}$ incision in its posterior wall.

A 3-cm segment of the radial artery was exposed so that proximal and distal vascular bands could be applied, transecting and ligating all its small branches. The arteriotomy was performed on the anterior wall of the artery utilizing a microsurgical scalpel, and care was taken not to damage the posterior wall of the artery. The incision was completed with microsurgical scissors. A thin catheter was introduced proximally and distally for injection of a heparin saline solution. Two cardinal stitches were made in the proximal and distal corner of the arteriotomy, and a sideto-end arteriovenous anastomosis was performed by using 4 separate $7 / 0$ or $8 / 0$ prolene running sutures, depending on the caliber of the vein. After the release of the vascular bands, pulsation and thrill were immediately palpated at the site of the fistula. The skin incision was closed with nonabsorbable 5/0 separate sutures.

In the patients in whom the cephalic vein at the forearm was not available, or in whom a previous radiocephalic fistula had failed, the second option was to create a fistula at the elbow. A 3-cm transverse incision across the antecubital fossa was made, and the basilica or cephalic vein was exposed, with special care to avoid damage to the medial cutaneous nerve of the arm. When the cephalic vein was utilized, a greater length of vein was obtained by performing another small incision at the lateral aspect of the forearm (Figure 1). After spatulating the terminal end of the vein, a side-to-end arteriovenous anastomosis was performed (Figure 2).

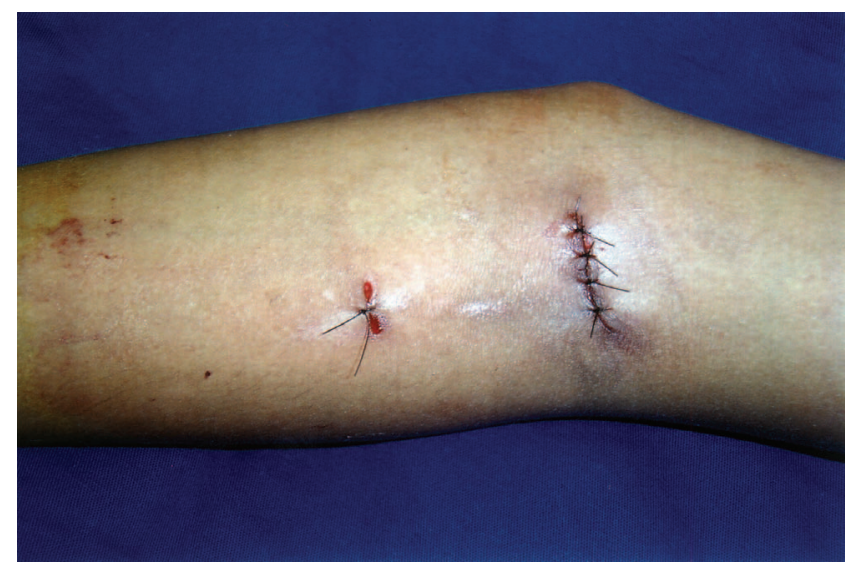

Figure 1 - Incisions used for the creation of brachiocephalic fistula.

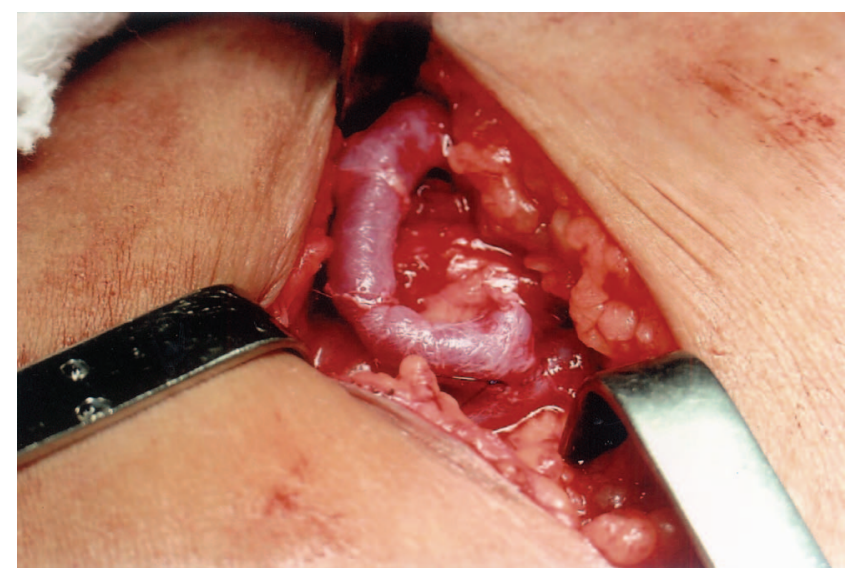

Figure 2 - Brachiocephalic arteriovenous fistula. Note the terminolateral anastomosis of the vein to the artery.

In cases of end-stage renal disease with superior vena cava thrombosis or of previously failed fistulas in the upper arm, the last choice was to perform a saphenofemoral fistula. A 4-cm longitudinal incision was created at the anterior crural region, and the saphenous vein was carefully dissected from all its collateral branches. The femoral artery was exposed and a wide side-to-end arteriovenous anastomosis was performed. No anticoagulant therapies or anti- 
biotics were used in the immediate postoperative period.

The surgical complications were analyzed in the immediate and late postoperative periods. During follow-up, the patency of the fistulas was assessed either by palpation for a thrill, auscultation for a bruit, or by using a Doppler probe.

Statistical analysis (Fisher-Yates test) was used to compare the immediate patency rate of the fistulas and the possibility for utilization for hemodialysis. A $P$ value of $<.05$ was considered significant.

\section{RESULTS}

A total of 29 children (16 males and 13 females - mean age of 8.1 years, ranging from 4 to 16 years) underwent surgery for 33 fistula creations - 21 radiocephalic, 6 brachiocephalic, 4 brachiobasilic, and 2 saphenofemoral. The mean operating time was about 2 hours and 15 minutes, and no patient required blood transfusion. Primary patency was achieved in $17 / 21(80.9 \%)$ of the radiocephalic fistulas (Figure 3), 5/6 (83.3\%) of the brachiocephalic, 3/4 $(75.0 \%)$ of the brachiobasilic, and $2 / 2$ (100\%) of saphenofemoral. Two patients with a radiocephalic fistula presented surgical complications in the first 24 postoperative hours, consisting of fistula occlusion and radial artery thrombosis. These complications were surgically treated by the passage of a Fogarty catheter into the radial artery and fistula. Although the radial arterial pulse returned to normal, fistula patency could not be obtained. Two other radiocephalic fistulas occluded in the first or second postoperative week. These four patients underwent surgery for creation of a new brachiocephalic or brachiobasilic fistula.

All the AVFs could be used for hemodialysis, but they required an interval of 3 to 4 weeks after surgery before they were sufficiently developed. This delay corresponds to the period of fistula maturation and could be diminished by a program of regular hand exercise. During this period, a dou-

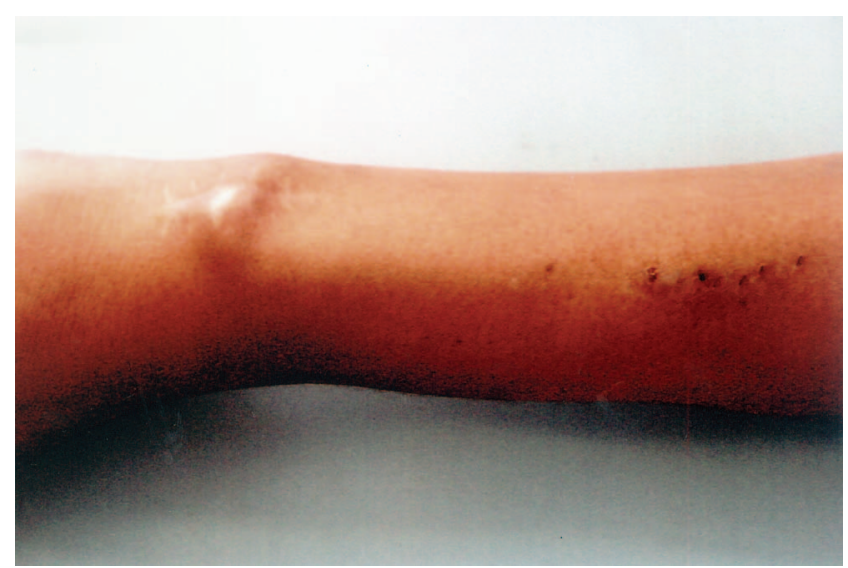

Figure 3 - Patent radiocephalic arteriovenous fistula in a girl weighing $15 \mathrm{~kg}$. ble-lumen central venous catheter was utilized for dialysis.

In the late postoperative period, the saphenofemoral fistulas were responsible for significant edema formation in the lower extremity 3 weeks after the surgery. Despite that, the fistulas could be regularly utilized for hemodialysis. An aneurysm formed in a brachiocephalic fistula after a long period of utilization.

As to the patency of the different sites of fistulas, the brachiocephalic and brachiobasilic fistulas had the same incidence of patency as the radiocephalic fistulas $(P>.05)$.

\section{DISCUSSION}

Our previous experience with liver transplantation techniques and vascular anastomoses encouraged us to start performing the AVFs at our institution in children with endstage renal disease.

Vascular access for chronic hemodialysis should meet the following criteria: long-term patency rate, low complication rate, and good acceptance by the child. Our clinical experience demonstrates that all these aims can be fulfilled with AVFs. The alternative techniques for hemodialysis in children, such as long-term central venous catheters and artificial shunts, resulted in a high rate of infection and thrombosis in our extensive previous experience. ${ }^{6-8}$ However, in the majority of cases, central venous double-lumen catheters had to be used for hemodialysis during the period of fistula maturation.

The main purpose of the current study was to report our initial experience in performing AVFs in children, with special emphasis on the details of the surgical technique. Therefore, some data relative to the patients such as height, body mass index, primary renal diseases, and the results of the late follow-up are not reported in the present study.

The technical refinements herein described, mainly the use of microsurgical techniques and operating loupes, allowed for good magnification and precise dissection; therefore, vascular anastomoses could be performed easily in the distal forearm with results that are similar to those obtained by the same procedure in adults. Patency failure rates were observed in 6 of 33 AVFs (18.1\%), and this result is similar to reported pediatric series. ${ }^{9-11}$ The main causes of primary patency failure were the poor condition of the veins and the low arterial blood flow rate. It is important to stress that patients with chronic renal failure often have edematous arms and thrombosed superficial veins secondary to multiple venipunctures that reduce the number of available fistula sites.

Contrary to previous reports, we did not adopt the upper-arm ischemia technique with inflatable tourniquet. ${ }^{11,12}$ Despite the described advantages of this technique, mainly the avoidance of arterial spasm, minimal hemostasis, safer 
dissection of the main vessels, and the absence of clamping, we are not accustomed to using such devices. Therefore, we preferred to dissect the vessels with minimal trauma and ligate all the small collateral branches.

In our experience, in spite of the smaller caliber of the vessels at the wrist, radiocephalic fistulas had the same incidence of patency as the fistulas performed in the brachial artery in the antecubital fossa $(P>.05)$. This is an important point and leads to the conclusion that in pediatric patients in whom the cephalic vein at the forearm is available, the first option should always be to create a radiocephalic fistula.

In summary, this initial experience indicates that the AVF is a satisfactory method for providing chronic hemodialysis in children. The utilization of microsurgical techniques and some technical refinements herein described permit the attainment of high patency rates of the fistulas.

\section{RESUMO}

TANNURI U e col. Experiência em fístula artério-venosa para hemodiálise crônica em crianças: detalhes e refinamentos técnicos. CLINICS 60(1):37-40, 2005.

OBJETIVO: Relatar a experiência dos autores na execução de fístulas artério-venosas em crianças, com a utilização dos recursos da microcirurgia vascular, com especial ênfase aos detalhes de técnica cirúrgica.

MÉTODOS: Os pacientes foram operados entre julho de 1997 e março de 2004. Foram utilizadas lupas cirúrgicas (aumento de 3,5 vezes). Após a dissecção da veia e da artéria, a anastomose veno-arterial foi realizada de forma término-lateral, com quatro suturas contínuas de fio 7/0 ou 8/0.

RESULTADOS: Vinte e nove crianças foram operadas para a realização de 33 fístulas - 21 rádio-cefálicas, 6 bráquio-cefálicas, 4 bráquio-basílicas e 2 safeno-femorais. Obteve-se permeabilidade em 17/21 (80,9\%) fístulas rádiocefálicas, $5 / 6(83,3 \%)$ bráquio-cefálicas, $3 / 4(75,0 \%)$ bráquio-basílicas e 2/2 (100\%) safeno-femorais. 2 pacien- tes apresentaram obstrução da fístula e da artéria radial e 2 outras fístulas rádio-cefálicas obstruíram-se entre a primeira e segunda semana de pós-operatório. Tardiamente, verificou-se que as fístulas safeno-femorais causaram edema do membro inferior correspondente e houve formação de aneurisma em uma fístula bráquio-cefálica. Quanto à permeabilidade, verificou-se que as fístulas bráquiocefálicas e bráquio-basílicas apresentaram a mesma incidência de permeabilidade em comparação com as fístulas rádio-cefálicas $(p>0,05)$.

CONCLUSÃO: A presente casuística demonstra que as fístulas artério-venosas persistem como um bom acesso vascular para hemodiálise em crianças. A utilização de microcirurgia e alguns detalhes técnicos aqui descritos permitem a obtenção de bons índices de permeabilidade das fístulas.

\section{UNITERMOS: Acesso vascular. Fístula artério-veno-}

\section{sa. Hemodiálise. Veias}

\section{REFERENCES}

1. Brescia MJ, Cimino JE, Appel K, Hurwich BJ. Chronic hemodialysis using venipuncture and a surgically created arteriovenous fistula. New Eng J Med 1966;275:1089-92.

2. Wander JV, Moore ES, Jonasson O. Internal arteriovenous fistulae for dialysis in children. J Pediatr Surg 1970;5:533-8.

3. Broyer M, Loirat C, Gagnadoux MF, Cukier J, Beurton D, Vacant J. "By-pass" et fistule arterio-veneuse en vue de l'hemodialyse chronique chez lénfant. Arch Fr Pediatr 1973;30:145-61.

4. Bourquelot P, Wolfeler L, Lamy L. Microsurgery for hemodialysis distal arteriovenous fistula in children weighing less than 10 kg. Proc Eur Dial Transp Assoc 1981;18:537-40.

5. Yazbeck S, Oreagan S. Microsurgery for Brescia-Cimino fistula construction in pediatric patients. Nephron 1984;38:209-12.

6. Quinton WE, Dillard D, Scribner, BH. Cannulation of blood vessels for prolonged hemodialysis. Tr Am Soc Artif Int Organs $1960 ; 6: 104-8$

7. Tannuri U. Vias de acesso vascular. In: Maksoud JG. Cirurgia Pediátrica. 2nd ed. Revinter: Rio de Janeiro; 2003. p. 87
8. Mohaideen AH, Avram MM, Mainzer RA. Polytetrafluoroethylene grafts for arteriovenous fistulae. N Y State J Med 1976;76:21525 .

9. Brittinger WD, Walker G, Twinttenhoff T, Konrad N. Vascular access for hemodialysis in children. Pediatr Nephrol 1997;11:87-91.

10. Miranda ML, Cavalaro MA, Sanches CRDT, Burstorf-Silva J. Fístula artério-venosa em crianças. In XXI Congresso Brasileiro de Cirurgia Pediátrica, III Jornada de Cirurgia Pediátrica do Mercosul, Porto Alegre, 1999.

11. Shemesh D, Zigelman C, Olsha O, Alberton J, Shapira J, Abramowitz H. Primary forearm arteriovenous fistula for hemodialysis access - an integrated approach to improve outcomes. Cardiovasc Surg $2003 ; 11: 35-41$.

12. Bagolan P, Spagnoli A, Ciprandi G, Picca S, Leozappa G, Nahom $\mathrm{A}$, et al. A ten-year experience of Brescia-Cimino arteriovenous fistula in children: technical evolution and refinements. J Vasc Surg 1998;27:640-4. 